\title{
足尾地区における植生変化が周辺地域の 短期的な降水特性に与える影響に関する研究
}

\author{
EFFECTS OF THE VEGETATION CHANGE IN THE ASHIO DISTRICT \\ ON SHORT-TERM RAINFALL CHARACTERISTICS IN ITS \\ SURROUNDING REGION
}

\author{
小山 隼平 ${ }^{1} \cdot$ 夏井 志康 $^{2}$ 鈴木 善晴 3 \\ Junpei KOYAMA, Motoyasu NATSUI, Yoshiharu SUZUKI \\ 1学生会員 法政大学大学院 デザイン工学研究科都市環境デザイン工学専攻 \\ ${ }^{2}$ 正会員工修 (株) 建設技術研究所 \\ 3 正会員 工博 法政大学 准教授 デザイン工学部都市環境デザイン工学科
}

\begin{abstract}
In order to clarify effects of the vegetation change in the Ashio district on short-term rainfall characteristics in its surrounding region, the current study conducted statistical analysis of observation data and experimental numerical simulations of precipitation systems using a mesoscale meteorological model with past and present conditions of land cover. Results of the statistical analysis show that the frequency of short-term heavy rainfall with over $30 \mathrm{mmh}$ at the stations located 10 to $30 \mathrm{~km}$ north of the Ashio district show a slight decrease, which is a tendency totally different from other stations in the surrounding region. On the other hand, simulation results of 61 events show that the vegetation recovery in the Ashio district can cause such a frequency decrease of rainfall due to the impact of ground roughness increase on the location and frequency of convective cloud initiation, which indicates that the result of the statistical analysis can be attributed to the vegetation recovery.
\end{abstract}

Key Words : vegetation change, land cover, rainfall characteristics, ground roughness, mesoscale meteorological model

\section{1.はじめに}

栃木県日光市に位置する足尾地区 (旧栃木県上都賀 郡足尾町) では, 1870 年代からの足尾銅山の鉱山活動 を起因とする , 大規模な土裹流失や森林の荒廃現象が 長年の問題となっている1) . 荒廃の原因としては, 過度 の森林伐採，製錬所からの排煙による煙害，度重なる 山火事などが挙げられる.

森林の働きを失った山岳域からは大雨のたびに洪水 や土石流が発生し, 同地域を水源とする渡良瀬川の沿 岸住民に猛威を奮ったが，1956 年に設置された自熔製 錬設備 (亜硫酸ガスの除去装置) により煙害の被害が 大幅に軽減され，この期を境に本格的な緑化・治山事 業が行われるようになった ${ }^{1)}$. 今日では, 植生盤やへリ コプター緑化工などを利用した事業の成果が実を結び， 岩山と化した足尾地区周辺の山岳にも植生が回復しつ つある.ここで, 過去の空中写真をもとに推定された同 地区における荒廃地面積率の変化を図-1 に示す ${ }^{2)}$. 同 図より，同地区の荒廃地が 1947 年〜2000 年の約 50 年
間で概ね 20〜30\% 程度減少しており，また現地調査 からも多くの地域で植生の回復か確認されている.

一方，同地域においては，1998 年 8 月の栃木・福島 豪雨 (那須豪雨) をはじめ, 南からの風が卓越した状 況で足尾山地を卜リガーとして発生した線状対流系が 豪雨をもたらすケースが数多く観測されており，光の メカニズム等についてこれまで樣々な解析が行われて いる (例えば中北ら $\left.{ }^{3)}\right)$.しかしながら，同地域におけ る植生状態の変遷が降水現象にどのような影響を与え ているかについては, これまでほとんど調査・分析がな されていない . 後藤ら ${ }^{2), 4}$ が , 空中写真と観測值を用い て, 荒廃地面積と降水量の関係を解析しているが, 年降 水量および年最大日降水量のどちらの観点からも，植 生回復による有意な影響は確認されていない .

一般に, 植生などの土地利用・土地被覆の変化は, ア ルベドや潜熱フラックスの変化等を通じて, 年降水量 や河川流量など周辺地域の中長期的な水文特性や気候 特性に影響を及ぼすと考えられるが, 近年は, 雷雨な どの短期的な降水現象も含め, 樣々な降水システムを 


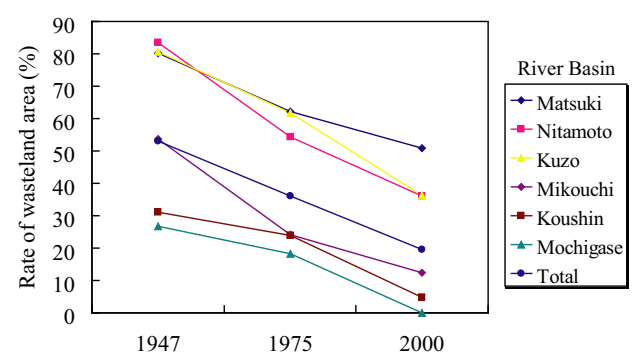

図-1 空中写真をもとに推定された足尾地区の各流域におけ る荒廃地面積率の変化 $\left(\right.$ 後藤 ${ }^{2}$ による推定結果を参考 にグラフを作成)

対象とした影響評価が行われている5)．

例えば，Pitman ら ${ }^{6)}$ は, 複数のモデルによる再現結 果と観測データを解析することでオーストラリア西部 の沿岸地域における降水量減少のメカニズムについて 検討を行い, 同地域における植生変化 (森林の減少) が 地表面粗度の低下と水平風速の増加をもたらし, 光の 結果, 水蒸気の収束域が内陸部入移動するようになっ たために光のような現象が生じたと述べている．

このように, 従来の研究の多くは, 観測に基づいた 統計的な解析あるいは数値モデルを用いた感度実験に より，森林や草原の農耕地化の影響や，ヒートアイラ ンド現象を含む都市化の影響などを明らかにしようと するものであるが, 弚れらの影響の現れ方は, 降水シ ステムのタイプや地理的な特性, 土地被覆の変化の程 度や空間的なパターンなどによって樣々であり，未だ 包括的な結論を得るには至っていない．

また, 足尾地区のように, 南からの風に起因する積 雲の発生頻度が高く線状対流系が形成されやすい地域 においては, 植生状態の変化が短期的な降水特性に対 して何らかの影響を及ぼしていることも十分予想され るが, 同地区の線状対流系や兰れがもたらす集中豪雨 を対象とした研究はほとんど行われていない．

乥こで本研究では, 足尾地区と光の周辺地域を対象 として, 植生変化が短期的な降水特性に与える影響を 明らかにするため, 気象庁気象統計情報を用いて統計 的な検討を行った．また，領域気象モデルWRF を用 いて, 同地区の植生状態を可能な限り再現した実験的 な数值シミュレーションにより植生变化前後の降水量 や降水分布がどのような変化傾向を示すかについての 解析を行った .なお, 本稿では, Pitman ら ${ }^{6)}$ が行って いるような，マルルモデル実験による有意性の検討を 目的とはせず，統計的な影響評価を目的とするシング ルモデル実験を実施した 。

\section{2. 気象統計情報を用いた降水特性の解析}

\section{（1）解析に使用した観測データの概要}

本研究では, 気象庁気象統計情報を用いた統計解析 を行った . 使用したデータは，足尾地区周辺の 6 観測 所 (足尾, 奥日光, 土呂部, 五十里, 那須, 宇都宮) で 観測された年降水量, 年最大日降水量, 年最大時間降

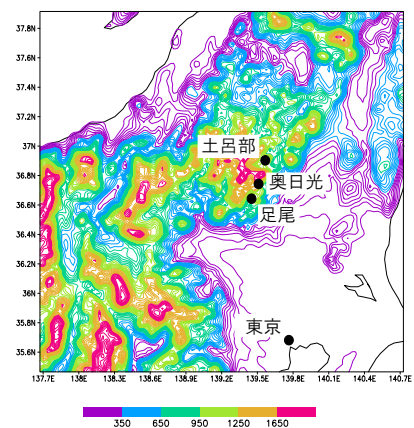

(1) 関東周辺

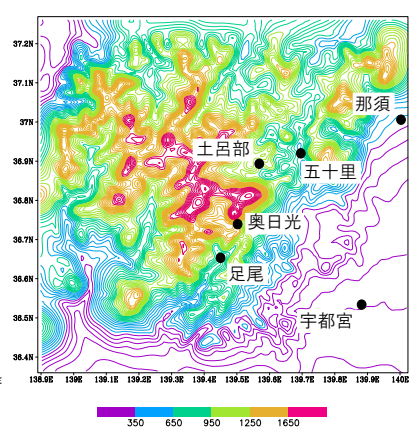

(2) 足尾地区周辺
図-2 関東周辺と足尾地区周辺の地形標高と 6 観測所の位置 (凡例は地形標高 $(\mathrm{m})$ )

水量で, 期間は 1980 年〜2012 年（ただし時間降水量 は 2009 年まで) とした .

関東周辺と足尾地区周辺の地形標高と各観測所の位 置を図-2に示す. 各観測所における降水量に対して , 5 年移動平均を適用した上て線形近似により回帰直線を求 めた . 谷の回帰直線の傾きについて T検定および Mann Kendall 検定を使用して，有意性の検定を行った .

\section{（2）足尾地区周辺の降水特性の解析}

まず，一例として，4観測所（足尾，奥日光，土呂部， 宇都宮) における年降水量の 5 年移動平均後の経年変 化, $30 \mathrm{~mm}$ 以上の時間降水発生回数の 5 年移動平均後

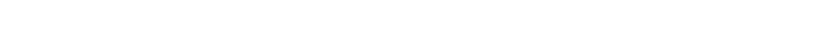
回帰直線を図-3に示す. 同図 (1) より, 年降水量は 4 観測所のいずれにおいても回帰直線の傾きが正の値を 示しており，長期的なトレンドは増加傾向にあること が分かる. また，足尾の年降水量に対する回帰直線の 傾きが，他の観測所よりも相対的に大きくなっている 同図 (2)では，足尾と宇都宮において過去から現在にか けて増加傾向であるのに対して，奥日光と土呂部にお いては減少傾向であることが特徵的である .

ここで, 全 6 観測所における年降水量，降水量極值 の回帰直線の傾きを一覧にして表-1に示す. 年降水量 , 降水量極値のいずれも, 多くの観測所で正の傾き (降 水量の増加傾向）を示している.これは，断定はできな いものの地球温暖化等の影響によるものと推測される . 年最大日降水量について見ると，奥日光と土呂部にお いて，負の傾きとなっている．また，年最大時間降水 量について見ると, 足尾, 五十里, 那須において正の 傾きとなっており，かつ，有意水準 $5 \%$ で有意な増加傾 向を示している. 奥日光では有意水準 $5 \%$ で有意な減少 傾向を示しており，土呂部，宇都宮に関しては光れ光 れ正，負の傾きを示してはいるが，弚の傾きは他の観 測所と比較して相対的に小さく，有意性が見られない，

次に，全 6 観測所における各閾値 $(10 \mathrm{~mm}, 20 \mathrm{~mm}$ ， $30 \mathrm{~mm})$ 以上の時間降水量発生回数における回帰直線の 傾きを表-2 に示す. $10 \mathrm{~mm}$ 以上の降水発生回数の傾き がすべて正の值を示しており，奥日光および土呂部を 除いた 4 地点の観測所の值は有意水準 $5 \%$ または $10 \%$ で 有意である.また，特徵的な傾向として，30 $\mathrm{mm}$ 以上 

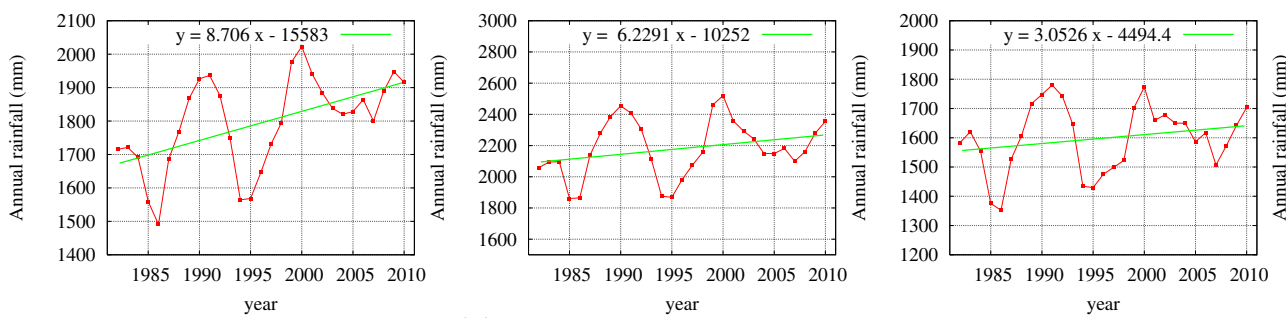

(1) 年降水量 (左から, 足尾, 奥日光 , 土呂部 , 宇都宮)
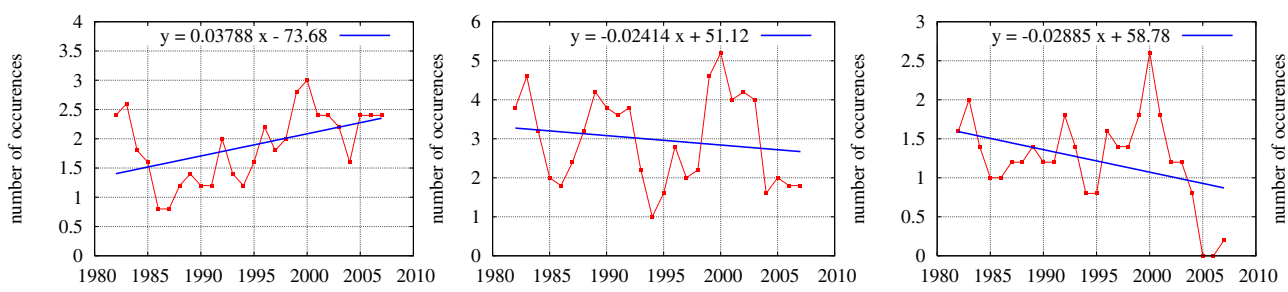

year (2) $30 \mathrm{~mm}$ 以上の時間降水発生回数 (左から, 足尾, 奥日光, 土呂部, 宇都宮)

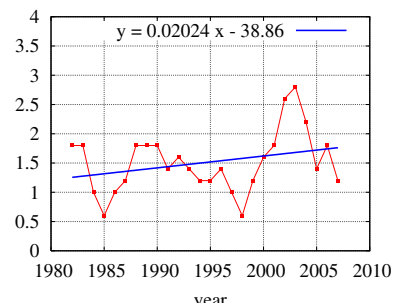

year

図-3 各観測所における年降水量および $30 \mathrm{~mm}$ 以上の時間降水発生回数の経年変化と回帰直線

表-1 各観測所における年降水量・年最大日降水量・年最大時 間降水量に対して求めた回帰直線の傾き

\begin{tabular}{|c|c|c|c|c|}
\hline 観測所 & 標高 & 年降水量 & $\begin{array}{c}\text { 年最大 } \\
\text { 日降水量 }\end{array}$ & $\begin{array}{c}\text { 年最大 } \\
\text { 時間降水量 }\end{array}$ \\
\hline \hline 足尾 & 650 & $8.706^{\circ}$ & 0.7039 & $0.2834^{\circ \bullet}$ \\
\hline 奥日光 & 1291 & $6.229^{\mathbf{}}$ & $\mathbf{- 0 . 5 8 5 9}$ & $\mathbf{- 0 . 3 6 1 9}$ \\
\hline 土呂部 & 925 & 3.053 & $\mathbf{- 0 . 2 5 7 9}$ & 0.001482 \\
\hline 五十里 & 620 & $8.481^{\circ}$ & $1.196^{\circ}$ & $0.5085^{\circ}$ \\
\hline 那須 & 749 & $15.65^{\circ}$ & 2.029 & 0.5076 \\
\hline 宇都宮 & 119 & $5.479^{\circ}$ & 0.2090 & -0.03374 \\
\hline
\end{tabular}

\: Mann Kendall 検定において有意水準 5 \% , 10\%で有意

の降水発生回数の傾きにおいて足尾, 五十里, 那須が 有意な増加傾向となっているのに対して, 土呂部，奥 日光では減少傾向 (土呂部では有意な減少) を示して いることが挙げられる .

これらから推測されることは, 足尾地区における植 生回復の影響を含む何らかの影響により同地区の降水 量が増加し, 兴の結果, 同地区の北方への水蒸気の移 流量が減少して 10〜 30km 北側に位置する土呂部や奥 日光における降水量極值の減少をもたらしたのではな いかと考えられる (土呂部は年降水量の傾きも若干小 さい）. また，隣接する土呂部と五十里の両観測所で明 らかに傾向が異なるのは, 奥日光と土呂部の間に位置 する標高 $2500 \mathrm{~m}$ 級の二つの山岳 (男体山・女峰山) の 影響や，周辺の地理的な要因によるものと考えられる なお，移動平均の年数の違いによる影響を検証する ため, 移動平均 3 年・ 5 年・ 7 年の比較を行ったが, 年 降水量, 日最大降水量, 時間最大降水量, 各閾値以上 の時間降水発生回数のいずれも大きな傾向の違いは見 られなかった .

次に, これらの降水量の变化が足尾地区における植 生回復に起因するものかどうかを検証するため，次節 では領域気象モデルを用いた数值実験により，降水の 発生頻度や風速場等に関する詳細な解析を行った .
表-2 各観測所における各閾值以上の時間降水発生回数に対し て求めた回帰直線の傾き

\begin{tabular}{|c|c|c|c|}
\hline 観測所 & $10.0 \mathrm{~mm}$ 以上 & $20.0 \mathrm{~mm}$ 以上 & $30.0 \mathrm{~mm}$ 以上 \\
\hline 足尾 & $0.2672^{\bigcirc \boldsymbol{\Delta}}$ & -0.00006838 & $0.03788^{\bigcirc \boldsymbol{\Lambda}}$ \\
\hline 奥日光 & 0.2347 & 0.03260 & -0.02414 \\
\hline 土呂部 & 0.1355 & -0.05990 & $-0.02885^{\triangle}$ \\
\hline 五十里 & $0.3634^{\bigcirc \bullet}$ & $0.1281^{\bigcirc \bullet}$ & $0.03665^{\circ}$ \\
\hline 那須 & $0.6286^{\bigcirc \bullet}$ & $0.1307^{\triangle}$ & $0.06455^{\triangle}$ \\
\hline 宇都宮 & $0.2254^{\bigcirc \boldsymbol{\Lambda}}$ & $0.07733^{\bigcirc \Delta}$ & 0.02024 \\
\hline
\end{tabular}

\: Mann Kendall 検定において有意水準 $5 \%$ ，10\%で有意

\section{3. 植生変化が降水特性に与える影響に関す る 数值実験の概要}

\section{(1) モデルの概要と本研究の計算条件}

本研究の数值実験には領域気象モデルのひとつであ る WRF (Weather Research and Forecasting model) を用いた.WRFは, 米国大気研究センター (National Center for Atmospheric Research)，オクラホマ大学, 米国海洋大気庁環境予測研究センター (NCEP) など によって共同開発されたモデルで, 水蒸気量, 雲, 雨, 雪, あられ，などの予報方程式からなる雲微物理モデ ルや，放射モデル，地表面モデル等の多数の力学法則 が取り入れられている .

本研究では, 3 つの Domain を用いて 2-way によるネ スティング計算を行った . 格子間隔を $3 \mathrm{~km}$ (Domain1)， $1 \mathrm{~km}$ (Domain2)，0.33km (Domain3) と設定し，Domain3 のグリッド数は $121 \times 121$ とした. 表-3 に本研究 で用いた WRF の物理過程のオプションを示す. 初期条 件及び境界条件として, メソ数值予報モデル $(\mathrm{MSM})$ GPV データ (気象庁提供, 解像度 $5 \mathrm{~km}, 3$ 時間間隔の 解析值) を使用し, 土猿温度, 土壤湿度, 及び海面水 温は客観解析データ FNL (NCEP 提供, 解像度 $30 \mathrm{~km}$ ) を使用した . 地形標高には, 国土地理院提供の数值地図 $50 \mathrm{~m}$ メッシュデータ, また土地利用情報として, 国土交 
表-4 各植生に対して設定された物理パラメータの值

表-3 本研究で用いた WRF の物理過程のオプション

\begin{tabular}{|l|l|}
\hline 雲微物理 & WSM6 \\
\hline 積雲過程 & None \\
\hline 短波放射 & Goddard shortwave \\
\hline 長波放射 & RRTM scheme \\
\hline 大気境界層 & Mello-yamada-Janjic scheme \\
\hline 地表面過程 & Noah land-surface model \\
\hline
\end{tabular}

\begin{tabular}{|c|l|c|c|c|c|}
\hline No. & \multicolumn{1}{|c|}{ 分類種別 } & $\begin{array}{c}\text { アルベド } \\
(\%)\end{array}$ & $\begin{array}{c}\text { 蒸発効率 } \\
(\%)\end{array}$ & $\begin{array}{c}\text { 粗度長 } \\
(\mathrm{cm})\end{array}$ & $\begin{array}{c}\text { 熱慣性 } \\
(\mathrm{W} / \mathrm{m} \cdot \mathrm{K})\end{array}$ \\
\hline 3 & 灌溉された耕作地 & 17 & 30 & 15 & 4 \\
\hline 5 & 耕作地と草原の混合 & 18 & 25 & 14 & 4 \\
\hline 7 & 草原 & 19 & 15 & 12 & 3 \\
\hline 15 & 混合林 & 13 & 30 & 50 & 4 \\
\hline 16 & 水面 & 8 & 100 & 0.01 & 6 \\
\hline 19 & 不毛, 疎らな植生 & 25 & 2 & 10 & 2 \\
\hline 32 & 都市 & 10 & 10 & 80 & 3 \\
\hline
\end{tabular}

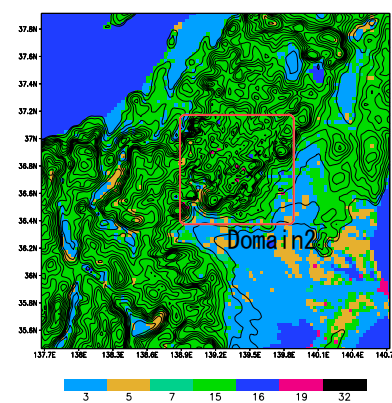

(1) Domain1 (Case2009)

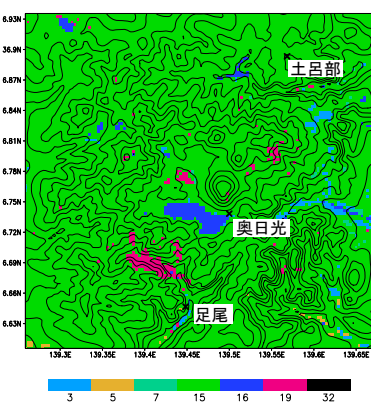

(3) Domain3 (Case2009)

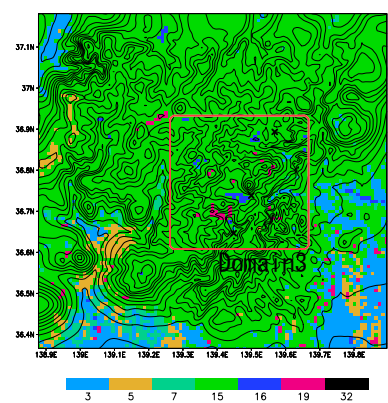

(2) Domain2 (Case2009)

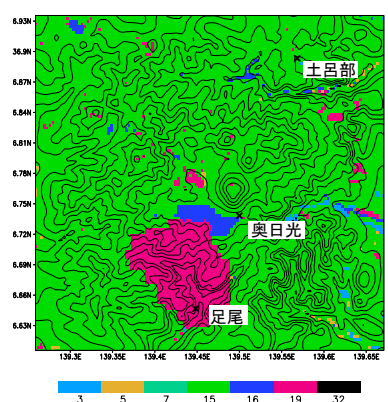

(4) Domain3 (Case1957)

図-4 設定領域における植生状態と領域内の地形標高 ( 凡例の数字は表-4 の分類 No. に対応する)

通省刊行の国土数值情報 $100 \mathrm{~m}$ メッシュデータを用い た .ここで本研究のシミュレーションで使用したWRF の主な植生分類と各植生に対して設定された物理パラ メータの值を表-4 に示す. 表 3 および表 4 については， 多数の既存研究を参考に標準的なものを設定した .

\section{（2）足尾地区の植生状態の設定}

本研究では, 足尾地域を対象領域として同地区の植 生状態を可能な限り再現した Case1957 と, 近年の植 生回復を反映した Case2009 の 2 つの土地利用データ を使用して，実験的な数值シミュレーションを行った 。 Case1957では, 1976 年度の土地利用データを基に , 参 考文献 ${ }^{1)}$ にある煙害地状況图を参照しながら一部地域を 人為的に植生変化させることで 1957 年前後の植生状態 を再現した .ここで植生変化 (裸地化) に用いた土地利 用分類は表-4 から No.19 (不毛または疎らな植生) を 使用した .また, Case2009では, 2009 年度の土地利用 データを用いて近年の植生状態を再現した . 各 Domain における植生状態と地形標高を図-4に示す (Case1957 は Domain3 のみ示す) . 図中に各観測所の位置を示し ており，南から足尾観測所，奥日光観測所，土呂部観 測所となっている .

また , 大気データとしては , 2010〜2013 年の 7 , 8 月

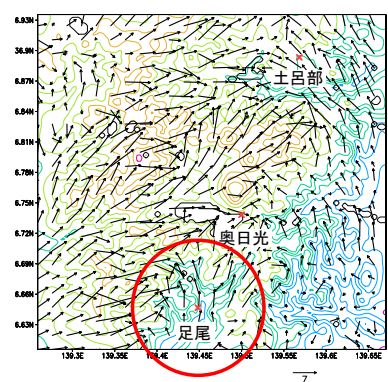

（1）風向と風速

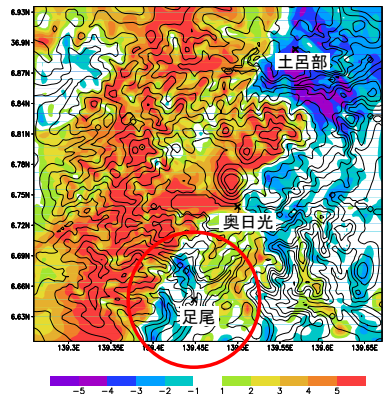

(2) 東西方向の風速 (東向き正)

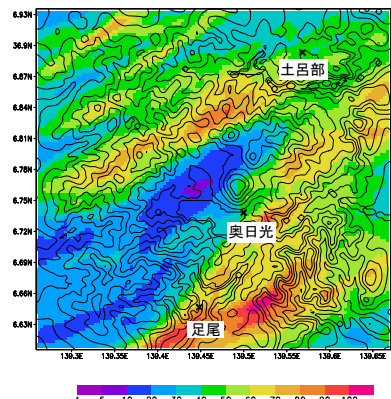

(3) 24 時間積算降水量
図-5 対象領域における日中の風向・風速及び 24 時間積算降 水量の一例 $(2011$ 年 8 月 18 日)

における降水か確認された日（全 134 日）のうち，台風 による事例とシミュレーションによって対象領域にお ける降水か確認されなかった事例を除いた 61 事例の大 気データを使用した . 各事例に対して 2 種類の土地利 用データ (Case1957 およびCase2009) を与え, 計 122 ケースのシミュレーションを行った (21 時 JST から 27 時間, このうち助走時間 3 時間) . 次節において数値実 験の結果と考察を述べる。

\section{4. 植生変化が降水特性に与える影響に関す る数値実験の結果と考察}

\section{（1）対象領域における風速場の傾向}

はじめに, シミュレーション結果の中から代表事例 として 2011 年 8 月 18 日の事例に着目し, 足尾地区周 辺の風の流れの傾向を見てみると，図-5に示すように 夏季の足尾地区では日中に太平洋側気候の特徵である 南風が確認できる．また，同図 (1) からは足尾観測所 周辺において, 南から北へと進む風の流れが, 東西二 手に分かれる樣子が見て取れる .これは足尾が備前楯 山 (標高 $1272 \mathrm{~m}$ ) と赤倉山（標高 $1442 \mathrm{~m}$ ) などの山に 囲まれた谷筋にあり，光の谷筋と平行に吹き込んだ風 が奥日光手前の山岳にぶらかって分流したと考えられ 


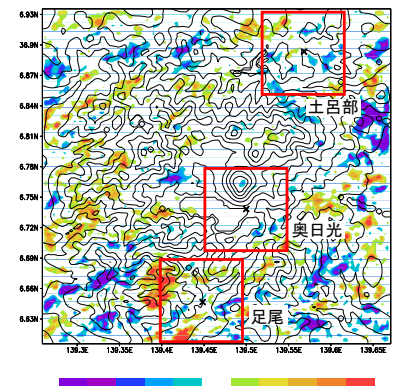

(1) $10 \mathrm{~mm}$ 以上 $20 \mathrm{~mm}$ 末満の 時間降水発生回数

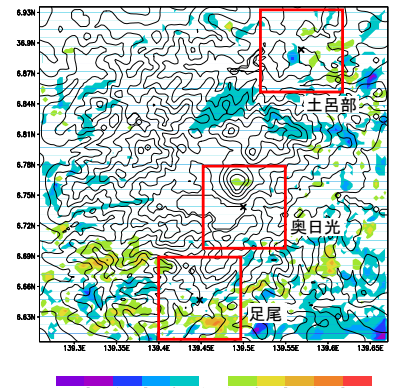

(2) $30 \mathrm{~mm}^{-5} \mathrm{~W}^{-2}$ 上の時間降水発 生回数

図-6 全 61 事例における階級ごとの時間降水発生回数の偏差 (Case2009 - Case1957)

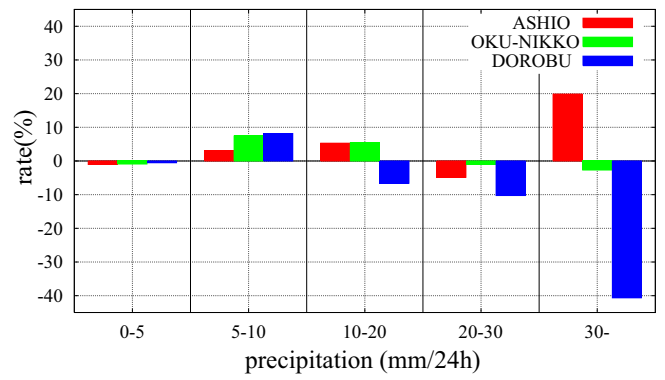

図-7 各領域における階級ごとの降水発生回数の増減率

る .また , 同図 (2)では, 奥日光以北において領域の西 側から西風，東側から東風か吹き込んでおり，特に，土 呂部観測所周辺において東西からの風の衝突が生じて いる. 兴のため, 足尾地区での植生変化が風下の奥日 光周辺および土呂部観測所周辺の気象現象に十分影響 を与え得る状況にあると考えられる．なお，他の事例 については, およ光半数の事例で 2011 年 8 月 18 日の 代表事例と同樣に南からの風が卓越しており，上記と 同樣の特徵を有していることか確認された .

\section{(2) 数值実験による降水量の変化傾向}

次に,全 61 事例 , 各 2 ケースのシミュレーション結果 を用いて, 階級ごとの時間降水発生回数および炎の偏差 (Case2009 - Case1957) を求めた . 図-6 に 10mm 以 上 $20 \mathrm{~mm}$ 末満の時間降水発生回数の偏差および, $30 \mathrm{~mm}$ 以上の時間降水発生回数の偏差を示す. 図中の赤枠は 各観測所を中心とした $100 \mathrm{~km}^{2}(10 \mathrm{~km} \times 10 \mathrm{~km})$ の領域 を表しており , 南から足尾エリア , 奥日光エリア , 土呂 部エリアとする．ここで，設定した各領域における階 級ごとの降水発生回数 (30×30 グリッドにおける発生 回数の合計值) の増減率を図-7 に示す.

図-6(1) および図-7 より，足尾エリアおよび奥日光 エリアにて $10 \mathrm{~mm}$ 以上 $20 \mathrm{~mm}$ 末満の時間降水発生回数 の増加が確認される . また , 図-6(2) および図-7より $30 \mathrm{~mm}$ 以上の時間降水発生回数は, 足尾エリアと土呂 部エリアにおいて傾向が大きく異なっており，足尾で は約 20\%の増加，土呂部では $40 \%$ 以上減少する結果と なっている . 図-6(2) では奥日光と土呂部の間の領域に おいても顕著な減少傾向が見て取れる。

ここで, 図-7 と表-2 を比較すると，各対象領域およ び各階級 (特に $30 \mathrm{~mm}$ 以上) の降水発生回数は, シミュ

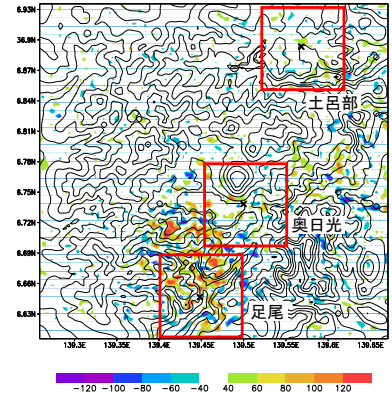

(1) 下層 (約 $1000 \mathrm{~m}$ )

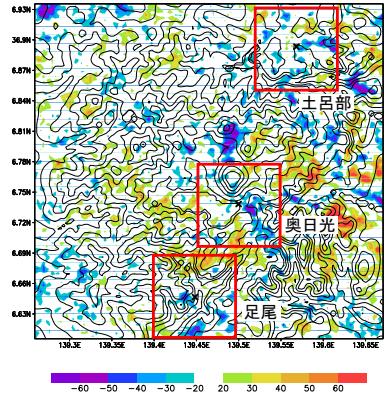

(2) 上層 (約 $8000 \mathrm{~m}$ )
図-8 $0.1 \mathrm{~m} / \mathrm{s}$ 以上 $0.3 \mathrm{~m} / \mathrm{s}$ 末満の上昇流発生回数の偏差

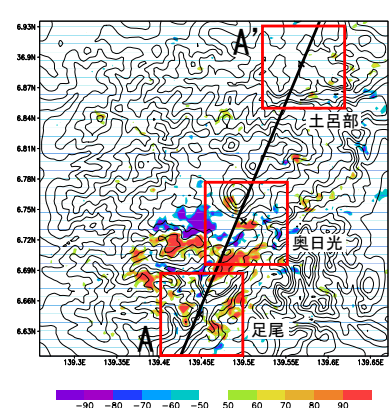

(1) 下層 (約 $1000 \mathrm{~m}$ )

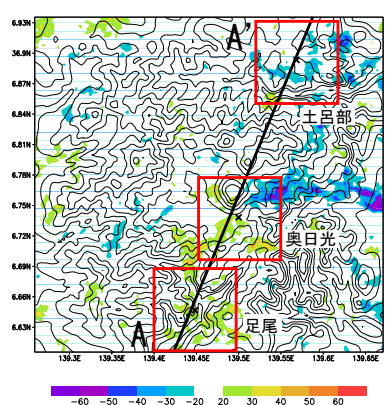

(2) 上層 (約 $8000 \mathrm{~m}$ )
図-9 $0.3 \mathrm{~m} / \mathrm{s}$ 以上の上昇流発生回数の偏差

レーション結果と観測值の間で増加・減少の傾向がお おむね一致する結果となった .

\section{（3）数值実験による上昇流の変化傾向}

降水量と同樣に，全 61 事例のシミュレーション結 果を用いて上昇流に関する解析を行った $.0 .1 \mathrm{~m} / \mathrm{s}$ 以上 $0.3 \mathrm{~m} / \mathrm{s}$ 末満の上昇流発生回数と $0.3 \mathrm{~m} / \mathrm{s}$ 以上の上昇流 発生回数および光れらの偏差 (Case2009-Case1957) を求めた . 各階級光れ光れの大気下層 (高度約 $1000 \mathrm{~m}$ ) と大気上層 (高度約 $8000 \mathrm{~m}$ ) における発生回数の偏差 を図-8, 図-9 に示す。

図-8(1) および図-9(1)より，大気下層ではどちらの 階級でも過去から現在にかけて足尾エリアで発生回数 の増加が見られる . 足尾周辺の植生が回復したことに より地表面粗度長の值が大きくなり，水平風速の減衰 と収束量の増加をもたらし，兴の結果，同地区で対流 の発生が促進されたと考えられる．図-9(2) を見ると， 大気上層における $0.3 \mathrm{~m} / \mathrm{s}$ 以上の上昇流が，足尾エリア と奥日光エリアの南部で増加しており, 光の北側に位 置する土呂部エリアでは減少傾向が確認される .

（4）植生変化が降水特性に与える影響とそのメカニズ ムに関する考察

次に，図-9 に示した A-A $\mathrm{A}^{\prime}$ 断面での $0.3 \mathrm{~m} / \mathrm{s}$ 以上の上 昇流発生回数の偏差 (Case2009 - Case1957) と植生 回復前後の大気の流れに関する概念図を図-10に示す 図-10の縦軸は標高を示している . 同図を見ると，図8(1) および図-9(1) と同樣に下層で植生回復後の上昇流 発生回数の増加が確認できる．また，下層で上昇流の 発生が顕著な足尾エリアでは, 上層にも上昇流の増加 傾向が見て取れる．これらの結果から，図-10(2) に示 


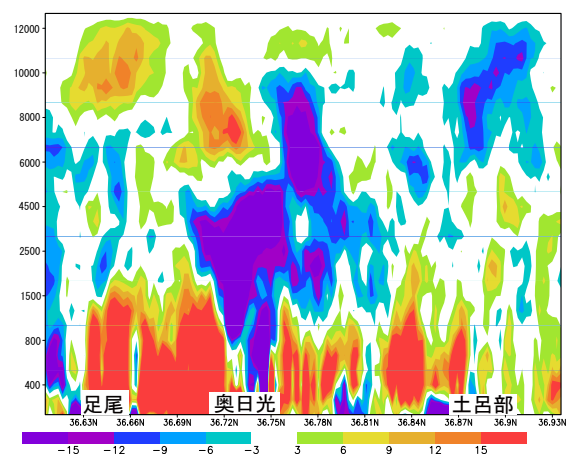

(1) $0.3 \mathrm{~m} / \mathrm{s}$ 以上の上昇流発生回数の偏差

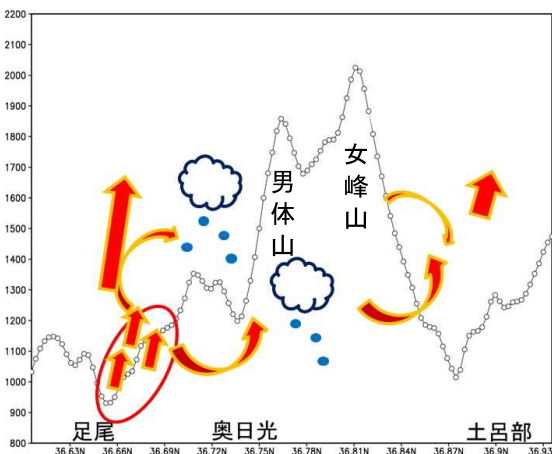

(2) 植生回復後 (2009 年)

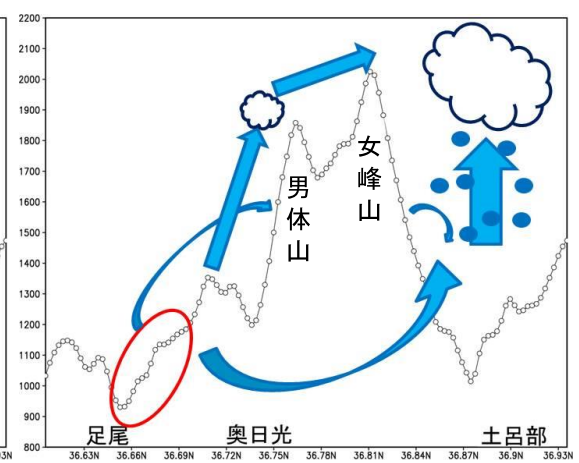

(3) 植生回復前 (1957 年)

図-10 上昇流の発生回数の偏差と植生回復前後の大気の流れに関する概念図（縦軸は標高 $(\mathrm{m}))$

すように，地表面付近で発生した上昇流か廭雲の発生・ 発達を促し，光の結果足尾における時間降水量極值の 増加をもたらしたのではいかと考えられる。

また，奥日光上空および土呂部上空にて植生回復後 の上昇流発生回数の減少, すなわち植生回復前の上昇 流発生回数の増加が確認される. 回復前の植生では地 表面粗度長が小さく, 水平風速の減衰と収束量の増加が 発生しないまま山岳 (男体山·女峰山) に風がゔつかり, また山岳の裏側の風が回り込むことによって，図-10(3) に示すように奥日光上空および土呂部上空にて上昇流 が発生したと推察される.この上昇流が, 過去の植生 状態における奥日光と土呂部においての時間降水量極 值の増加（すなわち, 過去から現在にかけての減少傾 向）をもたらす原因となったと考えられる．

本研究が対象とした足尾地区では, 山岳をトリガー として複数の積雲 (対流セル) が次々と発生・発達する ことから，Pitman ら ${ }^{6}$ が扱った事例と同樣に，積雲発 生領域における地表面粗度の変化による影響を強く受 けたと考えられる .モデル内で植生変化に用いた No.19 の植生 (不毛または疎らな植生) は, 粗度長パラメー 夕の值 (すなわち地表面の摩擦) が森林の場合の 5 分 の 1 と小さく, また蒸発効率も 15 分の 1 と非常に小さ い. 足尾地区における局地的な植生の回復は, 地表面 粗度長や蒸発効率を増加させることとなり，同地区に おける水平風速の減衰と収束量の増加，また，上昇流 の発生回数の増加及び水蒸気量の増加をもたらし, 積 雲の発生・発達の促進による降水発生回数の増加につな がったと考えられる.一方，足尾地区において降水発 生回数が増加したことにより, 兴の風下側に位置する 奥日光および土呂部への水蒸気の移流量が減少し, 積 雲の発生・発達が抑制され, 兴の結果, 風下域におけ る降水量の減少につながったと推察される .

\section{5. まとめ}

本研究では, 足尾地区と光の周辺を対象として, 植 生変化が短期的な降水特性に与える影響を明らかにす ることを目的として，気象庁気象統計情報を用いた統 計的な検討と領域気象モデルWRF を用いた数值シミュ レーションを行った．弚の結果，足尾観測値の解析か らは, 同地区の $10 \sim 30 \mathrm{~km}$ 北側に位置する観測所 (奥
日光，土呂部）において，日降水量および時間降水量 の極值が横ばいあるいは減少傾向にあり，さらに，強 い時間降水の発生回数では減少傾向が表れており，周 辺の他の観測所とは大きく異なる傾向を示すことが明 らかとなった .

領域気象モデル WRF を用いた解析では，過去と現 在の植生状態を再現した土地利用データを用意し，全 61 事例 (計 122 ケース) のシミュレーションを行った . 光の結果, 降水発生回数の増加, 減少の傾向が観測值 とおおむね一致する結果となった．また，風速場の解 析からは, 足尾周辺における局地的な植生の変化が上 昇流の発生位置及び発生回数に影響を与え, 兴の結果， 対象領域周辺の積雲の発生・発達を促進または抑制す ることにより, 経年変化での増加傾向または減少傾向 が生じた可能性が高いことが確認された .

\section{参考文献}

1) 秋山智英 : 森よ、よみがえれ - 足尾銅山の教訓と緑化 作戦，第一プランニングセンター，1990。

2) 後藤明 : 足尾地域の治山事業に伴う流出特性の变遷に関 する基礎的研究, 宇都宮大学工学部建設学科卒業論文, 2008 .

3) 中北英一 - 矢神卓也 - 池淵周一: 1998 那須集中豪雨の 生起・伝播特性, 水工学論文集, 第 44 巻, pp.109-114, 2000.

4) 後藤明・池田裕一：足尾地域の治山事業に伴う流出特性 の変遷に関する基礎的研究, 第 35 回土木学会関東支部 技術研究発表会講演概要集 (CD-ROM) ，2-76，2008.

5) Pielke, R. A. , J. Adegoke, A. Beltran-przekurat, C. A. Hiemstra , J . Lin , U. S. Nair, D. Niyogi and T. E. Nobis: An overview of regional land-use and landcover impacts on rainfall, Tellus , 59B , pp.587-601, 2007.

6) Pitman ,A. J. , G. T. Narisma , R. A. Pielke, and N. J. Holbrook: Impact of land cover change on the climate of southwest Western Australia, J. Geophys. Res. , 109 , D18109 , doi:10.1029/2003JD004347, 2004.

(2014. 9. 30 受付) 